\title{
Pedagogical Love and Good Teacherhood
}

Kaarina Määttä and Satu Uusiautti

University of Lapland

\section{Author Note}

Correspondence concerning this article should be addressed to Kaarina Määttä, P.O. Box 122, 96101 Rovaniemi, Finland. e-mail: Kaarina.maatta@ulapland.fi, or Satu Uusiautti, Lepolantie 29, 01830 Lepsämä, Finland (May-Sep) / 2403 SE 8th Ave, Cape Coral 33990, FL, USA (OctApr). e-mail.s satu@uusiautti.fi

\begin{abstract}
The aim of the article is to discuss the concept of pedagogical love and its connections to teaching and learning from various perspectives, as well as to illustrate the connection of pedagogical love to other forms of love. Pedagogical love is a specific teaching attitude and concretely demonstrates that action in the teaching profession, with pedagogical love as the core, consists of trust in pupils' learning capacities and the desire to help pupils improve their abilities and talents. However, pedagogical love is not the only or easy solution to meeting different pupils' needs and various learning problems.
\end{abstract}

Keywords: pedagogical love; ordo amoris; education; successful teaching; joy of learning 


\section{Pedagogical Love and Good Teacherhood}

\section{Good Teacherhood is not Just Substance Knowledge}

Good teacherhood has been characterized in several ways at different times (e.g., Lancaster, 1974; Freire, 1997; van Manen, 1991; van Manen \& Li, 2002; Korthagen, 2004; Marcos, Sanchez, \& Tillema, 2011). The foci have changed over the course of time; yet, there has been something permanent in the expectations as well (Darling-Hammond, 2003; Feiman-Nemser, 2003). In addition to teachers' personality and individual characteristics and collaboration and social skills, substance knowledge has been considered important as well (e.g., Elliott, Isaacs, \& Chugani 2010; Jakku-Sihvonen, 2005; Wall \& McAleer, 2000). However, the fact that a teacher is capable when it comes to the above-mentioned aspects does not guarantee positive learning outcomes (Parker, Ndoye, \& Imig, 2009). Instead, the ability to help various learners to succeed and be inspired (whether the learners are children or adults) is crucial. A teacher's proficiency is manifested by the ability to look at the subject from a learner's point of view, to foresee the critical junctions in learning, and to design teaching to meet learners' information acquisition and collection processes (e.g., Zombylas, 2007). Thus, a teacher's professionalism results from versatile mastery of the content in teaching (Davis, 1993; Hansen, 2009). However, even this mastery does not seem to be enough.

For example, Uno Cygnaeus (1910) sublimely described good teacherhood in Finland by noting:

Knowledge cannot alone be ennobling. Knowledge has to be molded into living conviction that would lead into inner noble-mindedness. Teaching must be educative and marked by the spirit of diligence, not mugging up whatsoever but merely action that develops harmoniously soul and body. Every teacher has to blaze with the spirit of sacred love. Sacred love that does not seek its own, that does not look at the present but the future; love that can even punish when considered necessary. That kind of love towards pupils has to smolder in a teacher's heart. That kind of teacher's love affects the whole school in a protecting way. (p. 197)

Similarly, van Manen (1991) asks: "Is it possible to act as a real teacher if one is not oriented to children with loving care, trustful hope, and responsibility?” (p. 65). Furthermore, van Manen (1991) claims that as teachers embrace all children, regardless of their characteristics they become real educators, and thus, educators' pedagogical love becomes the precondition for pedagogical relations to grow (p. 66). Through hope-when considered merely as being present for a child than a kind of doing - the teacher shows a pupil that he or she believes and trusts in the pupil's possibilities (van Manen, 1991, pp. 67-68).

Indeed, teachers, if anyone, know that emotion-based attachments are bridges between people. Everyone should be able to feel love, caring, and attachment during their whole life, from birth to death (Fromm, 1956). Therefore, love cannot be ignored when reflecting good teacherhood-regardless of educational level.

In this article, we discuss what love in teaching means, how love is connected with teaching, and the significance of love in teaching and supporting pupils.

\section{The Many Faces of Love}

Love has many definitions and many faces as well (see Figure 1 ). In addition to romantic love (Beck-Gernsheim \& Beck, 1995; Fenchel, 2005; Hatfield, 1988; Hegi \& Bergner, 2010; Määttä, 
2005; Määttä, 2006; Person, 2007; Sternberg, 1998), there is friendship (Alberoni, 1987; Blieszner \& Adams, 1992; Fehr, 1996; Hartup, 1995; Miller \& Perlman, 2009), love for fellow humans (Eriksson, 1989; Janako, 1993; Paldanius, 2002), mother's and father's love, love of one’s country (Määttä, 2006), and pedagogical love (Haavio, 1948; Skinnari, 2004). All these forms of love have much in common and are threatened in the modern era of individualism and self-centered projects (Beck-Gernsheim \& Beck, 1995; Giddens, 1991); but they all are engaged in good teaching as well. Figure 1 illustrates the many forms of love and their interconnectedness.



Figure 1. The many faces of love $\mathrm{e}^{\underline{1}}$

Love for fellow humans, agape, is defined by the metaphor of the Good Samaritan and manifested in practice in welfare work (e.g., Aristotle, 1981; see also Fromm, 1956). Individualistic features, position, nationality, gender, abilities, race, or language do not determine a human being's value. Those differences based on skills, intelligence, or knowledge are insignificant compared with that basic human presence that is the same for all people: the right and need to be loved, accepted, and cared for as well as the right and need to grow and develop (Bradshaw, 1996; Lanara, 1981; Sprengel \& Kelly, 1992).

In nursing, this kind of love is contemplated through the concept of caring. Also, the concept refers to solicitude (Morse, Sohlberg, Neander, Bottorff, \& Johnson , 1990; Paldanius, 2002) as the caritas idea of compassion. At the core of nursing (Eriksson, 1989) is a salient love for fellow humans.

In addition, the ethics of caring (or bothering) concerns teaching (Gilligan, 1982). In fact, caring has been argued to be the central aim and method of education (see Noddings, 1988; Burns \& Rathbone, 2010). In this case, the emphasis is on the special value of empathy and concern for learners. A teacher's ethical caring means genuine caring, aspiring to understand and make an effort for pupils' protection, support, and development. Because of this pedagogical 
caring, the teacher especially pursues pupils' potential to develop and thus help them to find and use their own strengths.

Pedagogical love has been considered the core factor in the definition of good teacherhood for decades, though the characteristics of a good teacher have always included a variety of features. Features such as the ability to maintain discipline and order, set a demanding goal level, and the mastery of substance have been especially emphasized (e.g., Davis, 1993; Zombylas, 2007; Hansen, 2009). Consequently, even teacher education has focused more, for example, on teachers' didactic skills, as well as the ability to teach subjects and maintain social order (see e.g. Jakku-Sihvonen, 2005). Although love can be understood in different ways (as mentioned in the introduction), some may have considered it narrowly, without connecting it to teachers' work. Nonetheless, for instance, in Finland, Uno Cygnaeus wrote about pedagogical love in the 1860s and afterwards, a hundred years later, Martti Haavio (1948) and Urpo Harva (1955). Likewise, German phenomenologist Max Scheler (1874-1928, as cited in Solasaari, 2003) regarded values and love as the core of rearing.

\section{A Human Being is a Loving Creature}

According to Schelerian thinking (see Solasaari, 2003), a human being is fundamentally an emotional creature. A pupil's interest in his or her environment, its phenomena, object world, as well as within himself or herself, is primarily emotional by nature and only secondarily intellectual or willed. People concentrate on what pleases them and what they value. Scheler calls this outside-directed, intentional, interest love. Love arouses intellectual and logical thinking (Solasaari, 2003).

Thus, ordo amoris, ranking order created by love, develops. Ordo amoris determines people's action, choices, goals, and opportunities - even destiny. It originates from experiences, education, and teaching. People carry this love-based ranking order everywhere with them, but they also construct it in the different phases of their lives. Even the earliest philosophers-for example, Augustine, who defined the order of love as the brief and true definition of virtue in the $4^{\text {th }}$ century (see Fitzgerald, 1999), as well as Pascal in the $17^{\text {th }}$ century among others-talked about the order, logic, and reasons of the heart that brains do not comprehend. Hence, the logic of the mind is not the only way of understanding. (Solasaari, 2003; see also Barkow, Cosmides, \& Tooby, 1995; Collins, 2007).

Fundamentally, people are not only thinking or willing creatures, but also loving beings (cf. Kant, 1788/2000). Love influences the direction of people's action as well as its intensity. Positive emotions, joy, strength, and the feeling of being capable lead mental energy toward the desired goal (Rantala \& Määttä, 2011). Negative emotions, grief, fear, and anger cause entropy, an inner imbalance that burns off energy, brands the target with negative status, and pursues nullifying and undervaluing (e.g., Isen, 2001). Love as emotion and action creates hope and boldness (see, e.g., Määttä, 2010). Love, at its best, is manifested by the endeavour to make things develop, grow, and come forward, whether love falls on other people, art, science, ideas, or nature.

\section{What Can Be Done With Rearing?}

It was noted in classical Greece "a human being is not ready but something prospective that has to be built through rearing” (Aristotle, trans. 1981). People's actions are not just passive reacting, nor is their development determined only by these reactions; people function directed by their 
inner strengths and according to what kind of support, confirmation, and encouragement they receive. For example, a teacher's task is not just to praise pupils in order to strengthen their selfesteem, but also to provide them with informative learning-oriented, feed-forward comments that help low-achieving students to empower them as self-regulated learners (Engelsen \& Smith, 2010).

Max Scheler's philosophy of love emphasizes how important it is for people's development and learning that they learn to direct their interest and love, in addition to temporary pleasures, toward higher mental values and goals. The educator's task is to provide pupils with such stimuli and environment where students are guided to limit their instincts by controlling enjoyment and vital-based values, in order to be able to achieve higher values and skills (Solasaari, 2003).

High-grade capability requires daring, perseverance, and boldness to create one's own special field of interest. The courage to act according to one's own talents and be different from others, and the ability to put off temporal impulses, to self-discipline, are prerequisites of love and action that focus on higher mental values. Anything great cannot be achieved easily or without the passion of love (Määttä, 2011), which challenges modern teachers and educators. Today, concentrating on something of one's own that differs from others is not very fashionable. Many people prefer social acceptance and favour, tend to adhere to the same, well-matched mold with others, avoid differing from others, and, thus, sell their talent to acquire social favour and acceptance (Kerr, 1985; Uusikylä, 2008).

Skillful teachers know that remarkable scientific and artistic values are impossible to achieve without intensive concentration (Määttä, 2010). Phrasing one's own thoughts, refining one's special aptitudes, as well as building a strong identity, necessitate the ability to withdraw from others' company and the possibility to examine and be engrossed. The masters in practical fields seem to differ from others in their ability to follow strict training programs with enthusiasm and persistently for years (Csikszentmihályi, Rathunde, \& Whalen, 1996; Nicpon, 2011). This determination originates in emotional characteristics, says Daniel Goleman (1999, p. 109) and thus, highlights the power of love in directing activeness and vigour - which are also connected with the experience of flow.

\section{Flow as a Manifestation of Love}

At its magnificence, love appears as a so-called flow experience in many people's expertise and skillful doing. Mihaly Csikszentmihalyi $(1990,2000)$ has launched the concept that refers to an optimal or autotelic experience where people are riveted so comprehensively by a challenging performance that the awareness of time and place blurs. Flow is possible when the challenges in a task are balanced with an actor's abilities. Flow is an enjoyable state of concentration and task orientation, leading to optimal performance, whether the case is wall creeping, chess playing, dancing, surgery, studying languages, painting, or composing music.

Flow can be achieved when one is able to act to the maximum of one's skills and at a suitable challenging level (Csikszentmihalyi, 1990), which is quite similar to Augustine's notion of moments of the soul's attentiveness (see Fitzgerald, 1999). This sets challenges for skill development. If a task is too easy, it will bore. If it is too difficult, it will cause anxiety and fear. The exact experience of flow and the active sense of well-being resulting from the former, encourage people to develop and improve their skills. People are willing to strive for flow whether it was about love for math, art, programming, or orthopedics (Csikszentmihalyi, 1990). 
In addition, Howard Gardner, the developer of the theory of multiple intelligences, considers flow and the positive states of mind of love and joy one of the healthiest ways of rearing children. In an interview, Gardner (as cited in Goleman, 1999) said flow is intrinsically rewarding without the hope for reward or threat of punishment. We should use learners' positive moods (love) and through it get them to learn things about fields they can succeed in. People have to discover what they like, what things and doings they love and do these things. Even a child learns the best when he/she loves what he/she is doing and finds it enjoyable. (p. 126)

Pedagogical love might contribute to pupils’ learning and success by providing them with positive learning experiences, initial excitement, and perceived successes. These are the seeds of expertise as a positive feeling that can be considered the source of human strengths (Isen, 2001). The special characteristics in this kind of positive behaviour are, for example, optimism, hope, perseverance, wisdom, happiness, creativity, and flow (Nakamura \& Csikszentmihalyi, 2006).

Likewise, failures can be significant for learning as long as the individual absorbed in the task does not have to feel threatened. A salient question concerning good teacherhood is: What makes a learner boldly seize new challenges, act actively for his or her own learning, and not back away from the challenges (see, e.g., Hakkarainen, Lonka, \& Lipponen., 2004; Diener, 2000)? Therefore, pedagogical love would rather aim at the discovery of pupils' strengths and interests and act based on these to strengthen students' self-esteem and self-image as active learners.

\section{What is Pedagogical Love, Then?}

Education and teaching that aims at bringing out personalities cannot succeed without a loving attitude, says Martti Haavio (1948), one of the most significant forces of Finnish education in the 1950s and 1960s. Haavio emphasized the meaning of pedagogical love in teachers' work and considered that teachers' work consists of the following two obligations: attachment to learners and dutiful perseverance of life values. Pedagogical love springs from an individual learner's presence persuading it to come forward more and more perfectly and diversely. A skillful educator does not just sit by and watch if a learner makes worthless choices or fails in his or her opportunities to grow and develop.

Indeed, Haavio (1948) highlights the moral nature of pedagogical love: Pedagogical love is addressed to every learner regardless of his or her various outer abilities, features, appearance, behaviour, or personality traits. Pedagogical love is a way of teaching, not just "a natural feeling" (Haavio, 1948, p. 71). As a teaching method, "a teacher's pedagogical love will not become dependent on how a pupil responds to a teacher's love” (Haavio, 1948, p. 71), nor does it aim at pleasing pupils or spoiling them but steeling themselves for work, endurance, and self-discipline. Pedagogical love does not try to keep a pupil in constant dependency with a teacher, nor allow a youngster to become independent (Haavio, 1948). Pedagogical love speaks to interdependencethe recognition and acceptance that we need others.

Love appears in teaching as guidance toward disciplined work, but also as patience, trust, and forgiveness. The purpose is not to make learning fun, easy, or pleasing but to create a setting for learning where pupils can use and develop their own resources eventually proceeding at the maximum of their own abilities. A teacher's love for a pupil embodies, according to Schelerian thinking, a continuous trust that there is more in a learner than is shown outside. This is, for example, in line with Aristotle's opinion about love as wishing good for other people for their sake (Aristotle, 1981). Indeed, love has many faces: It covers feelings, acts, attitudes, and learned 
models. It directs acts and action and lays the foundation for motivation and interest. Love for doing, expertise, and creativity is crucial among teachers and pupils. Furthermore, pedagogical love may sound self-sacrificing. However, we want to consider it merely as good teacherhood, as well as a method and attitude in the sense that it involves firm trust in pupils' abilities and, therefore, also requires determined and persistent work in order to show this trust. Pedagogical love is not just about unselfishness, but can also have a clearly selfish intention and desire to prove to oneself and others what can be achieved through teaching - the ability to engage students through the teacher's own pedagogical engagement is a rewarding source of satisfaction for a teacher.

The logic of love elicits hidden skills and opportunities even if the logic of the mind has already given up. For instance, in situations where a learner's progress is slow or tangled, a loving teacher takes care that the learner does not lose his or her trust in his or her own learning when getting frustrated. When a teacher believes in a learner's abilities, the teacher will find it easier to convince the learner of them as well. In addition, love appears as goal-oriented action: A teacher plans and implements learning situations that enhance learning. In practice, this means using quite simple techniques, such as concretizing, illustrating, asking questions, discussing, listening and repeating, thanking for the small steps forward, providing remedial or supplementary instruction, making the standards lower temporarily in order to make time for maturing, and not giving up or quitting easily. Furthermore, a loving teacher takes a pupil's personal situation into consideration (e.g., van Manen, 1991; Hatt, 2005).

A loving teacher reveals for a pupil the dimensions of his or her development in a manner of speaking. This is how a pupil's self-esteem strengthens and he or she can develop toward higher activities from the lowest, pleasure-oriented ones. Achieving high-level skills is rewarding because it brings pleasure, and yet, it often demands-as mentioned previously_selfdiscipline and rejections. Without a teacher's support, a pupil can easily remain at the level where gaining pleasure is easy and effortless (e.g., Katz \& Tello, 2003). Thus, pedagogical love is not irrational sentimentalizing or weak-willed following. It is a working method that involves persistent interest and perseverance to support pupils' development for the sake of themselves and the whole society. Pedagogical love is the fundamental principle and method for good teacherhood.

The irreplaceable nature of the method of pedagogical love is also confirmed by Erich Fromm's notion: “The perfect knowledge is possible only through love” (Fromm, 1994, p. 52). For example, the scaffolding technique can be considered a modern neighbouring concept for pedagogical love because this technique emphasizes a teacher's role as a timely supporter. A teacher's task is to intervene in a learning process and support it when a learner's skills are not enough for completing a task. The goal is the principle of minimal help so that a teacher's role becomes smaller, little by little, and a learner develops survival strategies for him or her (Rantala \& Määttä, 2011). Similarly, Vygotsky's (1978) concept of the zone of proximal development dissects a learner's potential goals for achieving which he or she needs a teacher's help. Development takes place, first, interpersonally and then, as an individual's inner action. Guided by a teacher (or pedagogical love), a pupil can reach the actual developmental level.

\section{Is Pedagogical Love the Solution?}

Schoolwork and teaching can be defined as active stimulus to positive experiences of success and remarkable achievement and as a self-centered oasis of positive emotions. Considered from 
this point of view, they appear certainly as an encouraging and promising teaching reality. Most teachers and students would want this, but it has its shadow side as well. As desirable as pedagogical love and its consequences may be, fantasizing about such altruistic teaching has accompanying risks.

This two-dimensional image of a teacher's role as aiming at pupils' success can strengthen a myth about teacherhood in which pupils' performance results from a teacher's pedagogical solutions, choices, attitudes, and capability, in other words, teaching skills. Learning is not just pleasure-centered joy, nor does it consist of top experiences that can be chosen by one's own fancies or pointers given by a teacher-not even when a pupil is talented. The risk is also that a pupil's failure, fatigue, reluctance, or inability to concentrate would be interpreted as the pupil's inefficiency or the shortcomings of a teacher's proficiency.

A teacher's work is interpersonal and relational, with a teacher's own personality fundamental to building relationships with students. A teacher's work involves plenty of emotional strain. In addition, a teacher inevitably has to experience frustration in his or her work. There are many situations when a teacher will feel like she or he has failed regardless of the solution he or she creates.

Empathy, caring, and love in a teacher's work are often problematic. Arlie Hochschild (1983) refers to a teacher's work as emotional work where a teacher shapes and controls emotions appropriately. The prevailing emotional rules at school necessitate that a teacher actively produces certain emotions of nurturing and caring, and denies or grows apart from the inappropriate moods of negligence. Consequently, teachers are likely to experience guilt because they cannot sufficiently attend to all pupils in an appropriate way that is congruent with the notion of caring. Erving Goffman (1981) points out the same by claiming how emotional deviation among teachers causes strain or stress. This is likely to happen when a teacher has an unbecoming, unfamiliar, or wrong kind of emotional orientation for confronting pupils in a teaching situation. The school community defines the emotional rules according to which emotions can be expressed appropriately. Emotional expressions and emotional language are delineated and regulated at school. Furthermore, the expression of emotions often varies by gender.

In the mix of multiple demands, a skillful teacher can prioritize the demands of his or her work. A teacher's engagement and drive are enhanced by the simple capacity to be happy about even the smallest achievements and by belief in a learner's ability and desire to work hard within a variety of learning experiences. However, teachers have to realize that their own coping, motivation, and engagement require attention; they are not automatic.

\section{Conclusion: The Vow of Pedagogical Love}

Pedagogical love emerges through teachers' emotions, learned models, moral attitude, and actions. They could be summarized in the following vow of teacher's pedagogical love that is based on Hartmut von Hentig's paper in Die Zeit-periodical (nr. 39; Sep 19, 1991). Fundamentally, a good teacher is accountable to his or her pupils, along with the following principles: 
As a teacher and educator, I oblige myself

- to respect every learner's (also the weakest one) personality and defend them when necessary if they are not capable or when innocent to those circumstances that weaken their growing environment;

- to answer for their physical and mental integrity;

- to notice their feelings and emotions in my action and regard them seriously;

- to consider every pupil's personality [just] as any adult's personality and pursue mutual understanding with them;

- to enhance their development according to their developmental principles and rhythms by noticing their special aptitudes;

- to protect learners from anxiety and the feelings of guilt when necessary and strengthen their self-esteem;

- to not to break their will and merely to help them to get their own mind under control when that mind seems quite "impossible";

- to prepare them to be responsible for societal matters;

- to allow them to experience what life can offer at its best; and

- to help them realize what could be a better world than the existing one and to believe that it is achievable.

Good teachers are examples to learners even in the most difficult life situations. Teachers have to believe in their work and endeavour to build a nurturing environment and a more humane world. At their best, teachers help pupils - children or adults - to experience their own potentiality and see what life can offer. Pedagogical love may guide a learner to consider the better world as achievable. The motto of The World's Teachers' Day 2003 refers to the same idea: "Teachers-Opening doors to a better world."

Without pedagogical love, teaching and learning may remain "as a form of effective management of learning and become a means only because it is presumed to offer a link between the intentionality of curriculum designers and the actual learning outcomes which are developed in learners” (Webster, 2009, p. 44).

To be happy about life, to guide students to see the wonder and joy in the mundane is a teacher's most important skill. Being able to help students find and negotiate the joy, wonder, happiness, and pain in the everydayness of life is an increasingly important quality in today's insecurities, with the mounting pressure of increased demands for efficiency. Learning the joy of life can be crucial for many learners in order to avoid or survive the darker depths of life. 


\section{References}

Alberoni, F. (1987). Falling in love. New York: Random House Inc.

Aristotle. (1981). Nikomakhoksen etiikka [The ethics of Nikomakhos]. (S. Knuuttila, Trans.). Helsinki, Finland: Gaudeamus.

Barkow, J. H., Cosmides, L., \& Tooby, J. (1995). Adapted mind, the evolutionary psychology and the generation of culture. Oxford: Oxford University Press.

Beck-Gernsheim, E., \& Beck, U. (1995). The normal chaos of love. Cambridge: Polity Press.

Blieszner, R., \& Adams, R. (1992). Adult relationships. London: SAGE.

Bradshaw, A. (1996). Yes! There is an ethics of care: An answer for Peter Allmark. Journal of Medical Ethics, 22, 8-13.

Burns, D. P., \& Rathbone, N. (2010). The relationship of narrative, virtue education, and an ethic of care in teaching practice. in education, 16(2). Retrieved from http://ineducation.ca/article/relationship-narrative-virtue-education-an...

Collins, J. (2007). Linguistic competence without knowledge of language. Philosophy Compass, 2(6), 880-895.

Cygnaeus, U. (1910). Uno Cygnaeuksen kirjoitukset Suomen kansakoulun perustamisesta ja järjestämisestä [Uno Cygnaeus's writings about the foundation and organization of the Finnish elementary school]. Helsinki, Finland: Kirjayhtymä.

Csikszentmihályi, M. (1990). Flow: The psychology of optimal experience. New York, NY: Harper and Row.

Csikszentmihályi, M. (2000). Beyond boredom and anxiety: Experiencing flow in work and play. San Francisco, CA: Jossey-Bass Publishers.

Csikszentmihályi, M., Rauthunde, K., \& Whalen, S. (1996). Talented teenagers: The roots of success and failure. Cambridge: Cambridge University Press.

Darling-Hammond, L. (2003). Keeping good teachers: Why it matters, what leaders can do. Educational Leadership, 60(8), 6-13.

Davis, B. G. (1993). Tools for teaching. San Fransisco, CA: Jossey-Bass Publischers. Diener, E. (2000). Subjective well-being: The science of happiness and a proposal for a national index. American Psychologist, 55(1), 15-23.

Elliott, E. M, Isaacs, M. L., \& Chugani, C. D. (2010). Promoting self-efficacy in early career teachers: A principal's guide for differentiated mentoring and supervision. Florida Journal of Educational Administration \& Policy, 4(1), 131-146.

Engelsen, K. S., \& Smith, K. (2010). Is “Excellent” good enough? Education Inquiry, 1(4), 415431.

Eriksson, K. (1989). Caritas-idea [The idea of Caritas]. Hämeenlinna, Finland: Karisto.

Fehr, B. (1996). Friendship processes. London: SAGE. 
Feiman-Nemser, S. (2003). What new teachers need to learn. Educational Leadership, 60(8), 2529.

Fenchel, G. H. (2005). What is love? Issues in Psychoanalytic Psychology, 27(1), 49-67.

Fitzgerald, A. D. (1999). Augustine through the ages: An encyclopedia. Grand Rapids, MI: William B. Eerdmans Publishing Company.

Freire, P. (1997) Pedagogy of the heart. New York, NY: Continuum.

Fromm, E. (1956). The art of loving. New York, NY: Harper Collins.

Fromm, E. (1994). Rakkauden vaikea taito [The art of loving]. (Trans. M. Luoma \& M. Matikainen). Helsinki, Finland: Kirjayhtymä.

Giddens, A. (1991). Modernity and self-identity. Self and society in the late modern age. Cambridge: Polity Press.

Gilligan, C. (1982). In a different voice. Psychological theory and women's development. Cambridge, MA: Harvard University Press.

Goleman, D. (1999). Tunneäly. Lahjakkuuden koko kuva [Emotional intelligence: The overall picture of talent]. (J. Kankaanpää, Trans.). Helsinki, Finland: Otava.

Goffman, W. (1981). Forms of talk. Oxford: Oxford University Press.

Haavio, M. (1948). Opettajapersoonallisuus [Teacher personality]. Jyväskylä, Finland: Gummerus.

Hakkarainen, K., Lonka, K., \& Lipponen, L. (2004). Tutkiva oppiminen - järki, tunteet ja kulttuuri oppimisen sytyttäjänä [Researching learning - mind, emotions, and culture as the lighters of learning]. Helsinki, Finland: WSOY.

Hansen, K. (2009). Strategies for developing effective teaching skills in the affective domain Journal for Physical and Sport Education, 23(1), 14-19.

Hartup, W. (1995). The three faces of friendship. Journal of Social and Personal Relationships, 12(4), 569-574.

Harva, U. (1955). Aikuiskasvatus. Johdatus aikuiskasvatuksen teoriaan ja työmuotoihin Suomessa [Adult education: introduction to the theory and work methods of adult education in Finland]. Helsinki, Finland: Otava.

Hatfield, E. (1988). Passionate and companionate love. In R. Sternberg \& M. Barnes (Eds.), The psychology of love (pp. 191-217). New Haven, CT: Yale University Press.

Hatt, B. E. (2005). Pedagogical love in the transactional curriculum. Journal of Curriculum Studies, 37(6), 671-688.

Hegi, L. E., \& Bergner, R. M. (2010). What is love? An empirically-based essentialist account. Journal of Social and Personal Relationships, Aug 27, 620-636.

Hochschild, A. R. (1983). The managed heart. Commercialization of human feeling. Berkelay, CA: University of California Press.

Isen, A. M. (2001). Some perspectives on positive affect and self-regulation. Psychological Inquiry, 11(3), 184-187. 
Jakku-Sihvonen, R. (2005). Kasvatustieteiden opetus ja asiantuntijan arkipätevyys [Education of the educational sciences and expert's everyday competence]. In Jakku Sihvonen, Ritva (Ed.), Uudenlaisia maistereita. Kasvatusalan koulutuksen kehittämislinjoja [New kinds of masters: developmental guidelines of education of the educational sciences] (pp. 125-150). Jyväskylä, Finland: PS-kustannus.

Janako, B. J. (1993). Caring is loving. Journal of Advanced Nursing, 18, 192-194.

Kant, I. (1788/2000). Kritik der pratischen Vernununft [Criticism of practical mind]. Stuttgart: Reclam.

Katz, L., \& Tello, J. (2003). “I love me!” How to nurture self-esteem. Scholastic Parent \& Child, 10(6).

Kerr, B. A. (1985). Smart girls, gifted women. Columbus, OH: Ohio Psychology Publishing Co.

Korthagen, F. A. J. (2004). In search of the essence of a good teacher: Towards a more holistic approach in teacher education. Teaching and Teacher Education, 20(1), 77-97.

Lanara, V. (1981). Heroism as a nursing value. Athens, Greece: Sisterhood Evniki.

Lancaster, O. E. (1974). Effective teaching and learning. New York, NY: Gordon and Breach.

Marcos, J. M., Sanchez, E., \& Tillema, H. H. (2011). Promoting teacher reflection: What is said to be done. Journal of Education for Teaching, 37(1), 21-36.

Miller, R., \& Perlman, D. (2009). Intimate relationships. Boston, MA: McGraw-Hill.

Morse, J., Sohlberg, S., Neander, W., Bottorff, J, \& Johnson, J. (1990). Concepts of caring and caring as a concept. Advances in Nursing Science, 13(1), 1-14.

Määttä, K. (2005) Kestävä parisuhde [Long-lasting intimate relationship]. Juva, Finland: WSOY.

Määttä, K. (2006). Rakastumisen lumous [The fascination of falling in love]. Juva, Finland: WSOY.

Määttä, K. (2010). How to learn to guide the young to love. Educational Sciences and Psychology, 2(17), 47-53.

Määttä, K. (2011). The dissertation process described by doctoral students in Finland. EInternational Journal of Educational Research, 2(1), pp. 66-80.

Nakamura, J., \& Csikszentmihalyi, M. (2006). Luovuuden motivationaaliset lähteet myönteisyyden paradigman kannalta [The motivational sources for creativity from the perspective of the paradigm of positivity]. In L. G. Aspinwall \& U. M. Staudinger (Eds.), Ihmisen vahvuuksien psykologia [The psychology of human strengths] (pp. 263-277). Helsinki, Finland: Edita.

Nicpon, M., Allmon, A., Sieck, B., \& Stinson, R. (2011). Empirical investigation of twiceexceptionality: Where have we been and where are we going? Gifted Child Quarterly, 55(1), 3-17.

Noddings, N. (1988). An ethic of caring and its implications for instructional arrangements. American Journal of Education, 96(2), 215-231. 
Paldanius, A. (2002). Lähimmäisenrakkaus hoitotyön koulutuksessa [Caring in nursing education]. Acta Universitatis Lapponiensis 45. Rovaniemi, Finland: University of Lapland.

Parker, M. A., Ndoye, A., \& Imig, S. R. (2009). Keeping our teachers! Investigating mentoring practices to support and retain novice educators. Mentoring \& Tutoring: Partnership in Learning, 17(4), 329-341.

Person, E. S. (2007). Dreams of love and fateful encounters. The power of romantic passion. New York, NY: W.W. Norton \& Co.

Rantala, T., \& Määttä, K. (2011) Ten theses of the joy of learning at primary schools. Early Child Development and Care. doi: 10.1080/03004430.2010.545124

Skinnari, S. (2004). Pedagoginen rakkaus. Kasvattaja elämän tarkoituksen ja ihmisen arvoituksen äärellä [Pedagogical love. Educator by the meaning of life and riddle of human being]. Jyväskylä, Finland: PS-Kustannus.

Solasaari, U. (2003). Rakkaus ja arvot kasvattavat persoonan - Max Schelerin kasvatusfilosofiaa [Love and values rear a personality - Max Scheler's philosophy of education]. Studies of the Department of Education in the University of Helsinki 187. Helsinki, Finland: University of Helsinki.

Sprengel, A., \& Kelley, J. (1992). The ethics of caring: A basis of holistic care. Journal of Holistic Nursing, 10, 231-239.

Sternberg. R. J. (1988). Love is a story. A new theory of relationships. Oxford: Oxford University Press.

Uusikylä, K. (2008). Naislahjakkuus [Female talent]. Jyväskylä, Finland: PS-publishing.

van Manen, M. (1991). The tact of teaching: The meaning of pedagogical thoughtfulness. London: Althouse Press.

van Manen, M., \& Li, S. (2002). The pathic principle of pedagogical language. Teaching and Teacher Education, 18, 215-224.

von Hentig, H. (1991). Der neue Eid [The new vow]. Die Zeit, 39, 19.9.1991, p. 76.

Vygotsky, L. (1978). Mind in society: The development of higher psychological processes. Cambridge: Harward University Press.

Wall, D., \& McAleer, S. (2000). Teaching the consult teachers: Identifying the core content. Medical Education, 34(2), 131-138.

Webster, R. S. (2009). Why educators should bring an end to pedagogy. Australian Journal of Teacher Education, 34(1), 42-53.

Zombylas, N. (2007). Emotional ecology: The intersection of emotional knowledge and pedagogical content knowledge in teaching. Teaching and Teacher Education, 23, 355-367.

\section{Endnote}

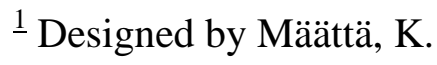

